\title{
Analisis Dan Usulan Solusi Sistem Untuk Mendukung Keputusan Penilaian Kinerja Dosen Menggunakan Metode Analytical Hierarchy Process (AHP)
}

\author{
Vivi Nila Sari ${ }^{1}$, Marta Widian Sari ${ }^{2}$, Sitti Rizki Mulyani ${ }^{3}$, SarjonDefit ${ }^{4}$ \\ Program Doktor Manajemen Universitas Putra IndonesiaYptk Padang \\ vivinilasari@upiyptk.ac.id ${ }^{1}$, martawidiansari@upiyptk.ac.id ${ }^{2}$, \\ sittirizkimulyani@upiyptk.ac.id ${ }^{3}$ sarjondefit@upiyptk.ac.id ${ }^{4}$
}

\begin{abstract}
Lecturer performance evaluation activities are a routine of a university in improving internal quality in a sustainable manner and improving accreditation status. University of Putra Indonesia Yptk Padang has not implemented the performance monitoring and evaluation of lecturers so far, resulting in impacts and obstacles for institutions in improving accreditation status and the difficulty for institutions in determining policies related to improving the quality of lecturers such as: further study, training and awards. In this study, a lecturer performance appraisal system will be developed using the Analytical Hierarchy Process method. The Analytical Hierarchy Process method is a decision support model that will describe complex multi-factor problems or multi criteria into a hierarchy. Based on the lecturer performance appraisal system developed, it will be used to build a decision support system to get outstanding lecturers at Putra Indonesia University Yptk Padang by using the analytical hierarchy process method. The research was in the form of developing a decision support system with information on the results of lecturer performance evaluations in implementing the tri dharma of higher education. The final results of the study took the form of appropriate and accurate decision making and were more effective in evaluating the performance of outstanding lecturers.
\end{abstract}

Keywords: Decision Support System, Analytical Hierarchy Process, Performance Evaluation.

\begin{abstract}
Abstrak- Kegiatan evaluasi kinerja Dosen merupakan rutinitas suatu perguruan tinggi dalam meningkatkan kualitas internal secara berkelanjutan serta peningkatan status akreditasi. Universitas Putra Indonesia Yptk Padang selama ini belum menerapkan pelaksanaan monitoring dan evaluasi kinerja Dosen, sehingga mengakibatkan dampak dan hambatan bagi institusi dalam peningkatan status akreditasi dan sulitnya bagi institusi dalam menentukan kebijakan terkait peningkatan kualitas Dosen seperti: studi lanjut, pelatihan dan penghargaan. Pada penelitian ini akan dikembangkan sistem penilaian kinerja Dosen menggunakan metode Analytical Hierarchy Process. Metode Analytical Hierarchy Process merupakan suatu model pendukung keputusan yang akan menguraikan masalah multi faktor atau multi kriteria yang kompleks menjadi suatu hirarki. Berdasarkan sistem penilaian kinerja Dosen yang dikembangkan, akan digunakan untuk membangun sistem pendukung keputusan untuk mendapatkan Dosen berprestasi di Universitas Putra Indonesia Yptk Padang dengan menggunakan metode analytical hierarchy process. Penelitian berupa pengembangan sistem pendukung keputusan dengan informasi hasil evaluasi kinerja Dosen dalam melaksanakan tri dharma perguruan tinggi. Hasil akhir dari penelitian berupa pengambilan keputusan yang tepat dan akurat serta lebih efektif dalam penilaian kinerja Dosen yang berprestasi.
\end{abstract}

Kata kunci: Sistem Pendukung Keputusan, Analytical Hierarchy Process, Evaluasi kinerja. 


\section{PENDAHULUAN}

Perkembangan teknologi informasi sekarang ini berkembang dengan begitu pesatnya, sehingga informasi dapat diperoleh dengan mudah, salah satunya adalah informasi pendukung keputusan. Pengambilan keputusan merupakan aktivitas utama manajemen yang sangat menentukan keberadaan suatu organisasi. Sejalan dengan perkembangan teknologi informasi, dikembangkanlah berbagai sistem pembantu manajemen di antaranya Sistem Pendukung Keputusan (SPK) yang berbasis komputer (Computer Based Decision Support System) yang dirancang untuk meningkatkan efektifitas pengambil keputusan dalam memecahkan masalah yang bersifat semi terstruktur atau tidak terstruktur [1]. Universitas Putra Indonesia Yptk Padang berupaya meningkatkan mutu atau kualitas internal secara berkelanjutan untuk dapat bersaing dengan perguruan tinggi lain. Salah satunya adalah peningkatan kualitas kinerja Dosen dengan cara melakukan monitoring dan evaluasi kinerja Dosen.

Analytical Hierarchy Process (AHP) merupakan suatu model pendukung keputusan yang dikembangkan oleh Thomas L. Saaty. Metode AHP telah banyak digunakan untuk membantu pengambilan keputusan, misalkan untuk "Pemilihan Karyawan Berprestasi" [2], "Pengembangan Produktivitas Hotel"[3], "Penentuan Pemilihan Calon Pejabat Struktural"[4], "Penentuan Sertifikasi Dosen"[5], "Menentukan Sisa Hasil Usaha Pada Koperasi Pegawai Negeri"[6],"Penentuan Pola Pengembangan Agrobisnis Jambu Mete"[7]. Pada makalah ini kami melakukan penelitian menggunakan metode AHP dalam melakukan pengambilan keputusan untuk mendapatkan Dosen berprestasi berdasarkan data-data penilaian kinerja Dosen Universitas Putra Indonesia Yptk Padang. Pengambilan keputusan tersebut didasarkan atas beberapa kriteria-kriteria yang digunakan dalam menilai kinerja Dosen, yakni pendidikan dan pengajaran, penelitian, pengabdian dan kegiatan unsur penunjang yang dilaksanakan oleh Dosen. Data yang kami kumpulkan merupakan data masing-masing kegiatan Dosen per semester. Tujuan penelitian adalah menganalisa dan menentukan solusi sistem pendukung keputusan untuk penilaian kinerja Dosen di Universitas Putra Indonesia Yptk Padang dengan menggunakan metode analytical hierarchy process.

\section{METODOLOGI PENELITIAN}

\subsection{SISTEM PENDUKUNG KEPUTUSAN (DECISION SUPPORT SYSTEM)}

Konsep Sistem Pendukung Keputusan (SPK) atau Decision Support System (DSS) pertama kali diungkapkan pada awal tahun 1970-an oleh Michael S. Scott Morton dengan istilah Manajemen Decision Systems [8]. Selanjutnya, sejumlah perusahaan, lembaga penelitian dan perguruan tinggi mulai melakukan penelitian dan membangun SPK. Penerapan SPK bertujuan untuk membuat keputusan dan meningkatkan efektivitas pengambilan keputusan dalam memecahkan masalahmasalah semi terstruktur.

Karakteristik dan kapabilitas kunci dari Sitem Pendukung Keputusan yaitu[9]: dukungan untuk pengambilan keputusan, dukungan untuk semua level manajerial, dukungan untuk individu dan kelompok, dukungan untuk keputusan independen dan atau sekuensial, dukungan di semua fase pengambilan keputusan, dukungan dari 
berbagai proses dan gaya pengambilan keputusan, adaptasi sepanjang waktu, pengguna merasa seperti dirumah, peningkatan terhadap keefektifan pengambilan keputusan, kontrol penuh oleh pengambil keputusan dalam memecahkan masalah, kemudahan pengembangan sistem oleh pengguna akhir, pemodelan dan analisis, akses data, standlone, integrasi dan berbasis web. Adapun struktur karakteristik dan kapabilitas kunci dari SPK ditampilkan pada Gambar 1.

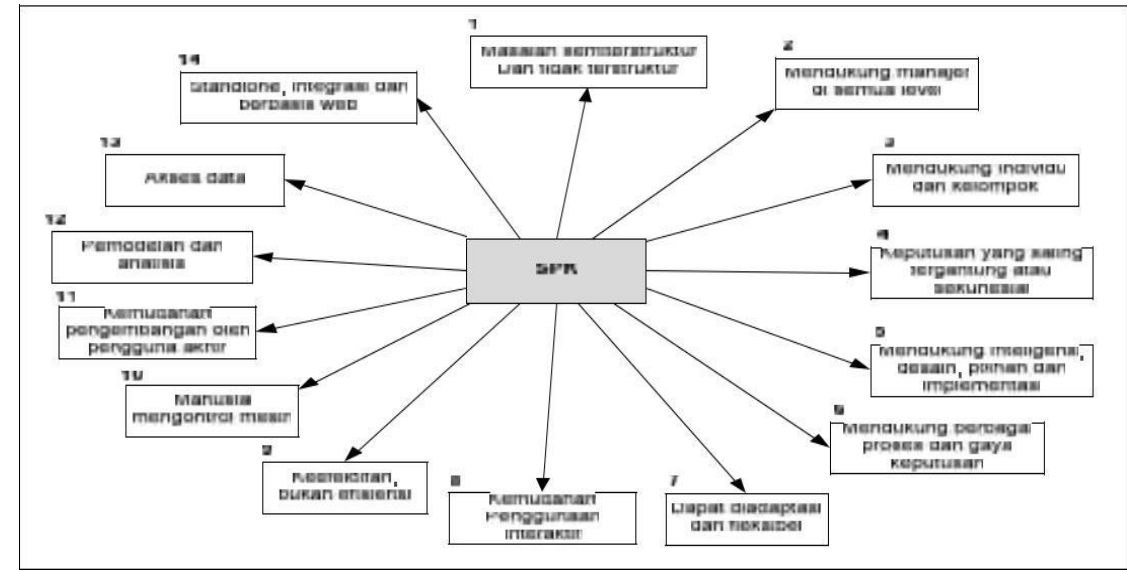

Gambar 1. Struktur karakteristik dan kapabilitas kunci dari SPK

Dalam penerapan SPK ada beberapa komponen subsistem yang digunakan yakni subsistem manajemen data, subsistem manajemen model, subsistem antarmuka pengguna, subsistem manajemen knowledge atau manajemen berbasis pengetahuan.

\subsection{METODE AHP (ANALYTICAL HIERARCHY PROCESS)}

AHP adalah teori pengukuran melalui perbandingan berpasangan dan bergantung pada penilaian para pakar untuk mendapatkan skala prioritas [10]. AHP pertama kali dikembangkan oleh Dr. Thomas L.Saaty dari Wharton School of Business pada tahun 1970-an untuk mengorganisasikan informasi dan keputusan dalam memilih alternatif yang paling disukai. Dengan menggunakan AHP, suatu persoalan yang kompleks yang tidak terstruktur, stratejik dan dinamik dapat dibuat menjadi bagian-bagian yang lebih sederhana dalam bentuk suatu hirarki. Adapun struktur hirarki AHP ditampilkan pada Gambar 2.

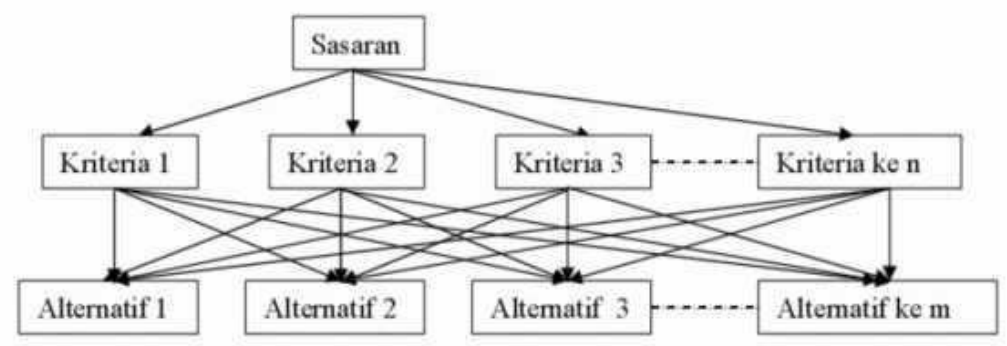

Gambar 2. Struktur Hirarki AHP (Saaty, 2008)

Prinsip dasar dan prosedur dari metode AHP adalah dengan cara judgement harus diperbaiki dengan mengulang langkah 3,4 dan 5 untuk seluruh tingkat hirarki. 
Namun jika nilai consistency index (CI) dibagi indeks random consistency (IR) hasil yang diperoleh kurang atau sama dengan 0,1 maka hasil perhitungan bisa dinyatakan benar atau konsisten. Dalam mengitung consistency ratio (CR), harus mengetahui standar baku indeks random consistency (IR) yang disesuaikan berdasarkan jumlah kriteria. Adapun daftar index random consistency (IR) ditampilkan pada tabel 1 [10].

Tabel 1. Daftar Index Random Consistency (IR)

\begin{tabular}{|c|c|c|c|c|c|c|c|c|c|c|c|c|c|c|c|}
\hline $\mathrm{N}$ & 1 & 2 & 3 & 4 & 5 & 6 & 7 & 8 & 9 & 10 & 11 & 12 & 13 & 14 & 15 \\
\hline $\mathrm{RI}$ & 0.00 & 0.00 & 0.58 & 0.90 & 1.12 & 1.24 & 1.32 & 1.41 & 1.45 & 1.49 & 1.51 & 1.48 & 1.56 & 1.57 & 1.59 \\
\hline
\end{tabular}

Sesuai dengan kebutuhan dalam penelitian ini langkah-langkah penelitian yang dilakukan adalah sebagai berikut:

1. Menentukan kriteria dan bobot masing-masing kriteria kinerja Dosen dengan mengikuti aturan standar dalam menentukan jabatan fungsional Dosen.

2. Menyusun hirarki dari permasalahan dan jenis-jenis kriteria yang dihadapi dengan menggunakan prosedur dari metode AHP.

3. Menyusun kriteria-kriteria tersebut dalam bentuk matriks perbandingan berpasangan (Pairwise Comparison).

4. Menjumlah nilai-nilai dari setiap kolom matriks perbandingan berpasangan.

5. Menghitung nilai elemen kolom kriteria.

6. Menghitung nilai prioritas kriteria.

7. Mengukur dan menghitung nilai konsistensi yaitu dengan menghitung lamda max (value eigen), consistency index (CI) dan consistency ratio (CR).

Menentukan kriteria dan bobot masing-masing kriteria kinerja dosen dengan mengikuti aturan standar dan menyusun kriteria-kriteria tersebut dalam bentuk matriks perbandingan berpasangan (Pairwise Comparison) yang dapat dilihat pada tabel berikut:

Tabel 2. Skala Dasar Perbandingan Berpasangan

\begin{tabular}{|l|l|}
\hline Intensitas Kepentingan & \multicolumn{1}{|c|}{ Keterangan } \\
\hline 1 & Kedua elemen sama pentingnya \\
\hline 3 & Elemen yang satu sedikit lebih penting daripada elemen yang lain \\
\hline 5 & Elemen yang satu lebih penting daripada yang lainnya \\
\hline 7 & Satu elemen jelas lebih mutlak penting daripada elemen lainnya \\
\hline 9 & Satu elemen mutlak penting daripada elemen lainnya \\
\hline $2,4,6,8$ & Nilai-nilai antara dua nilai pertimbangan pertimbangan yang berdekatan \\
\hline
\end{tabular}

\section{HASIL DAN PEMBAHASAN}

Sesuai dengan langkah-langkah penelitian diatas, pada pembahasan berikut ini akan dibahas tentang proses pengambilan keputusan penilaian kinerja Dosen dengan menggunakan metode AHP. Langkah awal adalah menentukan kriteria dan bobot masing-masing kriteria kinerja Dosen Universitas Putra Indonesia Yptk Padang dengan mengikuti aturan standar dalam menentukan jabatan fungsional Dosen. Kriteria-kriteria dan bobot kinerja Dosen yang digunakan adalah Kegiatan pendidikan dan pengajaran, Kegiatan penelitian, dan Kegiatan pengabdian[11]. Setelah menentukan kriteria dan bobot masing-masing kinerja Dosen, tahap 
selanjutnya adalah menyusun hirarki dari permasalahan dan jenis-jenis kriteria yang dihadap seperti pada Gambar 5.

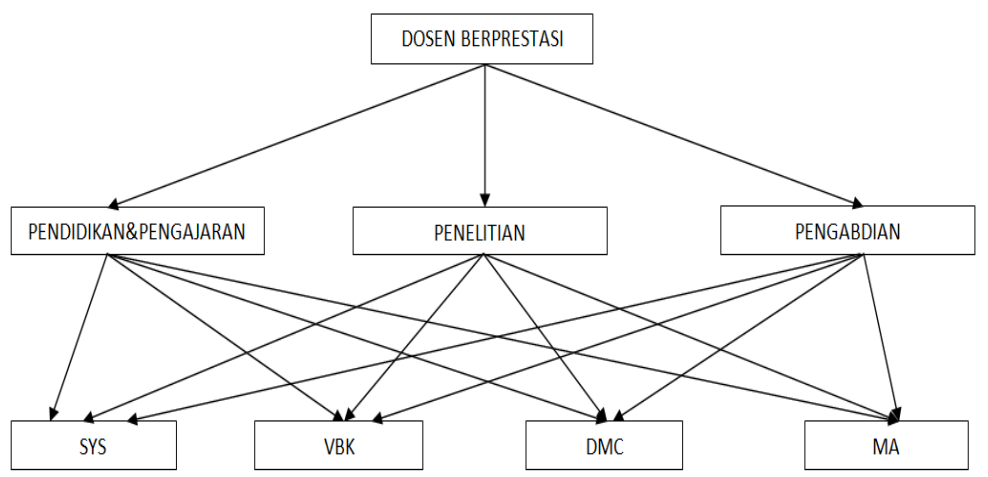

Gambar 3. Struktur Hirarki Kinerja Dosen

Setelah menyusun struktur hirarki diatas, tahap selanjut adalah menentukan prioritas elemen dengan cara menyusun kriteria-kriteria tersebut dalam bentuk matriks perbandingan berpasangan (Pairwise Comparison). Hasilnya ditampilkan sebagai berikut:

\subsection{Hasil Matrik Penilaian Kriteria}

Hasil matrik perbandingan kriteria akan disajikan pada gambar 2 berikut ini:

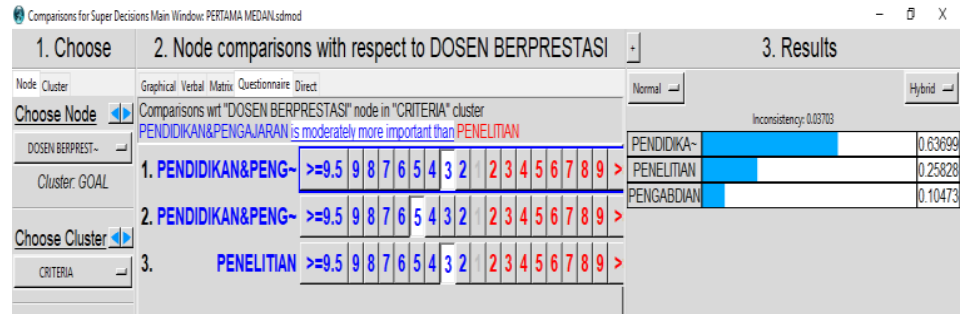

Gambar 4. Matrik Penilaian Kriteria

Berdasarkan hasil dari tabel 2 dapat kita lihat bahwa dari matrik kriteria di dapat nilai "Pendidikan dan Pengajaran $=0,63699$ ", "Penelitian $=0,25828$ ", "Pengabdian $=0,10473$ ", Dari ketiga kriteria tersebut dapat terlihat bahwa yang paling penting atau dominan dari kriteria yang dinilai adalah "Pendidikan dan Pengajaran" yaitu 0,63699 hal ini menunjukkan bahwa kriteria "Pendidikan dan Pengajaran" memiliki tingkat kepentingan 63,699\% dibandingkan dengan ktriteriakriteria lainnya. Hasil inconsistensy pada matrik kriteria ini berjumlah 1.

\subsection{Matrik Perbandingan Alternatif Pada Kriteria Orientasi Pendidikan dan Pengajaran \\ Perbandingan alternatif pada kriteria "Pendidikan dan Pengajaran" akan disajikan pada tabel 3 di bawah ini:}




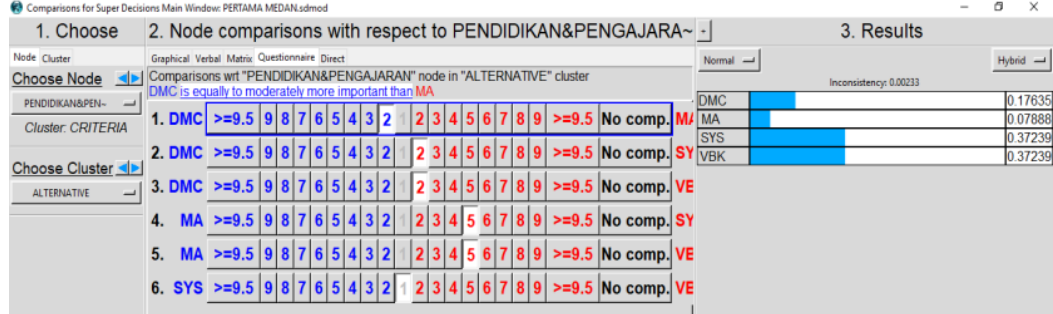

Gambar 5. Matrik Perbandingan Alternatif Pada Kriteria Orientasi Pendidikan dan Pengajaran

Dari hasil tabel 3 kriteria penilaian "Pendidikan dan Pengajaran" untuk SYS DAN VBK memiliki nilai kepentingan yang sama yaitu 37,239\%. Sedangkan DMC DAN MA masing-masingnya hanya memiliki nilai $17,635 \%$ dan $7,888 \%$. Nilai inconsistency pada matrik "Pendidikan dan Pengajaran" ini adalah 1.

\subsection{Matrik Perbandingan Alternatif Pada Kriteria Penelitian}

Hasil matrik perbandingan alternatif pada kriteria Penelitian dapat dilihat pada tabel 4 di bawah ini:

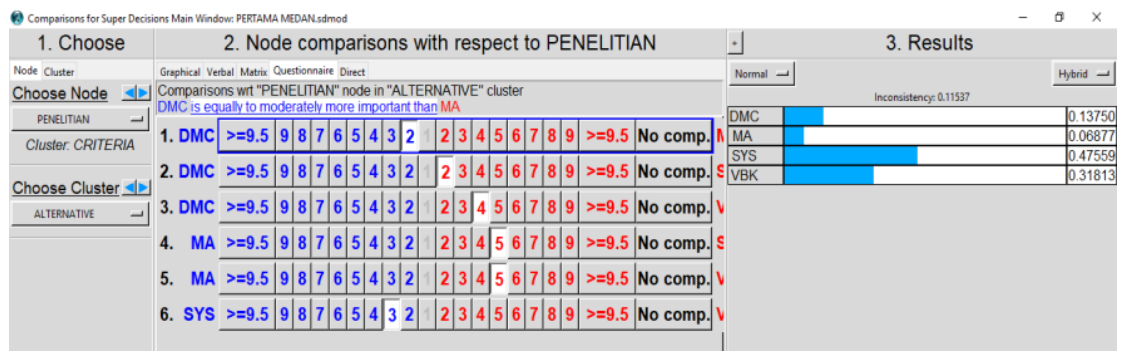

Gambar 6. Matrik Perbandingan Alternatif Pada Kriteria Penelitian

Dari tabel 4 dapat kita lihat bahwa nilai "Penelitian" SYS lebih tinggi dibandingkan yang lainnya yaitu sebesar 47,559\%. VBK memiliki nilai "Penelitian" ke dua tertinggi yaitu 31,813\%. Sedangkan DMC memiliki nilai "Penelitian" ke tiga tertinggi dengan nilai yang yaitu $13,750 \%$. Kemudian MA mempunyai nilai terendah yaitu dengan nilai 6,877 \%. Nilai inconsistency pada matrik "Penelitian" ini adalah 1.

\subsection{Matrik Perbandingan Alternatif Pada Kriteria Pengabdian}

Matrik perbandingan alternatif pada kriteria "Pengabdian" dapat dilihat pada Tabel 5 di bawah ini:

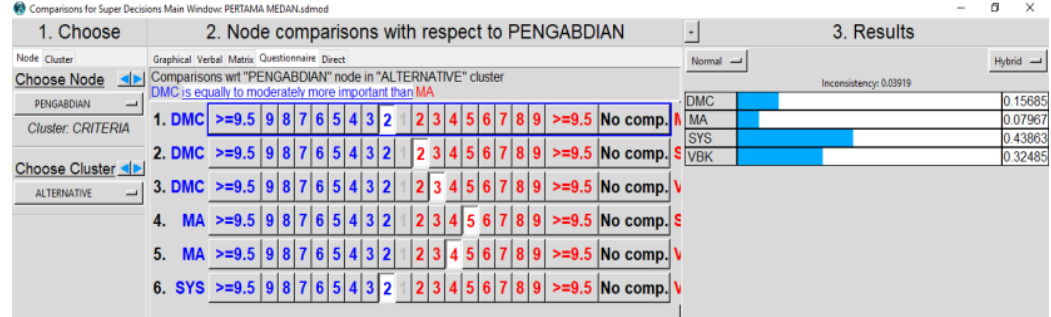

Gambar 7. Matrik Perbandingan Alternatif Pada Kriteria Pengabdian 
Berdasarkan Tabel 5 di atas dapat kita lihat bahwa SYS memiliki nilai tertinggi dibandingkan VBK, DMC dan MA yaitu 43,863 \%. Dan VBK memiliki nilai "Pengabdian" dibandingkan dua calon lainnya yaitu 41,660\%. Sedangkan DMC memiliki nilai "Pengabdian" 15,685 \% dan MA memiliki nilai 7,967\% . Nilai inconsistency pada matrik "Pengabdian" ini adalah 1.

\subsection{Hasil Komputasi (Computation Result)}

Untuk mendapatkan kesimpulan pilihan dari berbagai alternatif hasil dari sistem komputerisasi yang sudah dilakukan di atas, maka pengambil keputusan dapat membuat pilihan dengan melihat tabel kumputasi pada Tabel 6 di bawah ini:

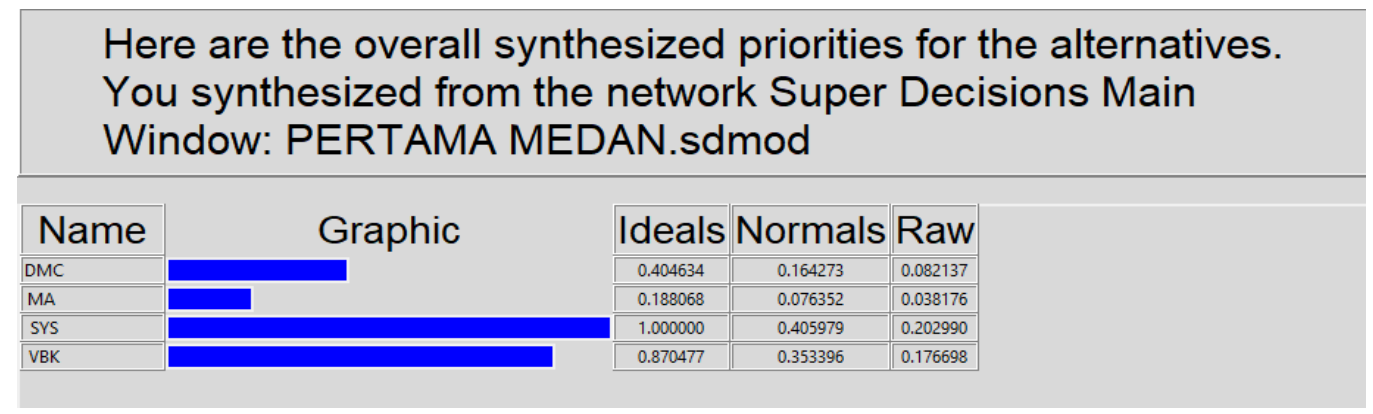

Gambar 8. Hasil Komputasi

Dari hasil komputasi pada Tabel 6 dapat dilihat bahwa SYS merupakan pilihan terbaik dari tiga yang lainnya berdasarkan kriteria-kriteria penilaian yang telah dilakukan di atas. SYS memiliki nilai komputasi tertinggi yaitu 40,5979\% pada kolom normalitas hasil secara keseluruhan dari semua kriteria yang dinilai. VBK merupakan calon pilihan ke dua dengan nilai komputasi 35,3396\%. DMC merupakan pilihan yang ke tiga dengan nilai komputasi 16, 4273\%. Dan MA merupakan pilihan yang ke empat dengan nilai komputasi terkecil yaitu 7, 6352\%. Nilai inconsistency normalitas pada hasil komputasi ini adalah 1.

Dari hasil komputasi ini dapat kita lihat bahwa jumlah nilai dari SYS menunjukkan bahwa SYS memiliki lebih kompetensi yang lebih tinggi sehingga nilai penilaian kinerja yang paling tinggi adalah SYS.

\section{KESIMPULAN}

Berdasarkan hasil analisa pengambilan keputusan penilaian kinerja Dosen menggunakan metode AHP dapat diketahui bahwa untuk karakteristik dengan tingkat keaktifan dalam menjalankan kegiatan Tridharma Perguruan Tinggi, maka nilai Rasio consistency lebih kecil. karena Dosen SYS selalu aktif dalam menjalankan pendidikan dan pengajaran, penelitian dan pengabdian. Dengan demikian maka metode AHP dapat digunakan untuk pengambilan keputusan penilaian kinerja Dosen, dengan kriterianya adalah kegiatan pendidikan dan pengajaran, kegiatan penelitian dan kegiatan pengabdian yang dilaksanakan oleh Dosen . Metode ini dapat dipakai untuk menganalisa dan menentukan solusi sistem pendukung keputusan untuk penilaian kinerja Dosen di Universitas Putra Indonesia Yptk Padang. 


\section{DAFTAR PUSTAKA}

[1] Turban, E., Volonino, L., 2010, Information Technology for Management, 7th Edition, Prentice Hall Inc, New Jersey.

[2] Amborowati, Armadiyah., 2006, Sistem Pendukung Keputusan Pemilihan Karyawan Berprestasi Berdasarkan Kinerja dengan Metode AHP, Seminar Nasional Aplikasi Teknologi Informasi (SNATI 2007), Jurusan Teknik Informatika UII, Yogyakarta.

[3] Yulia, dkk., 2006, Perancangan dan Pembuatan Sistem Pengambilan Keputusan untuk Pengembangan Produktivitas Hotel X dengan menggunakan Metode AHP dan OMAX, Seminar Ilmiah Nasional KOMMIT, Universitas Gunadarma Jakarta.

[4] Supriyono dkk., 2007, Sistem Pemilihan Pejabat Struktural Dengan Metode AHP, Seminar Nasional Aplikasi Teknologi Informasi (SNATI 2007), Jurusan Teknik Informatika UII, Yogyakarta.

[5] Rochmasari dkk., 2007, Penentuan Prioritas Usulan Sertifikasi Guru dengan metode AHP, Jurnal Teknologi Informasi, Volume 6 Nomor 1.

[6] Arifin, Zainal., 2010, Penerapan Metode Analytical Hierarchy Process (AHP) Untuk Menentukan Sisa Hasil Usaha Pada Koperasi Pegawai Negeri, Jurnal Informatika Mulawarman, Vol. 5 No.2.

[7] Indrawanto, Chandra., 2008, Penentuan Pola Pengembangan Agrobisnis Jambu Mete, Jurnal Littri Vol. 14 No. 2.

[8] Daihani, D. U., 2001, Komputerisasi Pengambilan Keputusan, Jakarta: PT Elex Media Komputindo Gramedia.

[9] Turban, E., et.al., 2005, Sistem Pendukung Keputusan dan Sistem Cerdas, Edisi 7, Andi.

[10] Saaty., 2008, Decision making with the analytical hierarchy process, Int. J. Services Sciences, Vol.1, No.1, University of Pittsburgh. Jandric,Z.

[11] Surat Keputusan Menteri Negara Koordinator Bidang Pengawasan Pembangunan dan Pendayagunaan Aparatur Negara Nomor: 38/KEP/MK.WASPAN/8/1999 tentang Jabatan Fungsional Dosen dan Angka Kreditnya. 